\title{
Effects of different drying methods on phenolic content, antioxidant capacity and general characteristics of selected dark colored Turkish fig cultivars
}

\author{
R. Konak ${ }^{1, a}$, İ. Kösoğlu ${ }^{1}$ and A. Yemenıcıoğlu ${ }^{2}$
}

${ }^{1}$ Food Technology Department, Fig Research Institute, 09600, Erbeyli, İncirliova, Aydın, Turkey; ${ }^{2}$ Department of Food Engineering, Faculty of Engineering, Izmir Institute of Technology, 35430, Güllübahçe, Urla, İzmir, Turkey.

\begin{abstract}
Fig fruit is a good source of minerals and crude fibers. The dark-colored fig cultivars rich in anthocyanins are also known with their high polyphenol content. However, although there are many different dark-colored fig cultivars grown in Turkey, the dried fig industry has traditionally been concentrated on drying of several yellow-colored fig cultivars. The aim of this study is to determine the effects of sundrying and oven-drying on some general characteristics, phenolic content and antioxidant capacity of 2 dark-colored (black) and 2 light-colored (yellow) fig cultivars selected from genetic collection of Turkish Fig Research Institute. The figs were obtained by harvesting at the semi-dry stage at $\mathbf{4 0 - 5 0 \%}$ moisture content and applying sun-drying or oven-drying to reach final moisture content between 20 and $26 \%$. The sun-drying was conducted on mats for 2-3 days under the sun while the oven-drying was applied for $12 \mathrm{~h}$ at $60^{\circ} \mathrm{C}$ and at the air velocity of $0,5 \mathrm{~m} \mathrm{~s}^{-1}$. The result of the study clearly showed almost 1,5-2 fold higher total phenolic content and ABTS free radical scavenging based antioxidant capacity of fresh dark-colored figs than fresh light-colored ones. The drying had almost no negative effects on the total phenolic content of both dark- and light-colored figs. The drying also did not have a negative effect on antioxidant capacity of light-colored figs, but it caused a limited reduction (between 20 and $30 \%$ ) in antioxidant capacity of dark-colored figs due to the well-known heat labile nature of their color compounds anthocyanins. The use of sun-drying or oven-drying did not have a considerably different effect on final phenolic contents and antioxidant capacities of dried figs. This study clearly showed that it is possible to obtain phenolic rich dried figs by use of dark colored fig cultivars such as TR1101 and TR1102.
\end{abstract}

Keywords: drying, antioxidant capacity, phenolic content, colored figs

\section{INTRODUCTION}

The fig is an important constituent of the classical Mediterranean diet which is considered to be one of the healthiest and is associated with longevity (Trichopoulou et al., 2006). Figs are rated among natural functional foods due to their considerably high dietary fiber and macro-micro nutrients. Particularly, the dark-colored (red or black) figs are excellent sources of phenolic compounds, such as proanthocyanidins (Vinson, 1999). In fact, some colored fig cultivars might contain higher phenolic contents than well-known sources of phenolic compounds such as red wine and tea (Vinson et al., 1998). However, the short shelf-life of fresh figs limits the trade of different cultivars with high functional properties in the global market.

The drying is an optimal solution to obtain shelf-stable figs and fig products. Also, dried fruits have more polyphenols and antioxidant content compared to the fresh fruits

${ }^{a}$ E-mail: ramazankonak15@hotmail.com 
(Vinson et al., 2005). Different drying methods including oven drying and sun drying are applied for drying of figs, but the best sugar/organic acid ratio is obtained by sun-drying that is applied to semi-dried fruits that ripens and wrinkles on the tree and falls down spontaneously to the ground (Özen et al., 2007). Although Turkey has many different fig cultivars, only two types of light-colored figs are used for industrial drying purposes. In the California six kinds of figs are cultivated for the dried fig market, but the only dark-colored cultivar used commercially is the 'Black Mission' cultivar (Haug et al., 2013).

Recent studies showed that there is a significant correlation among peel color of figs and their phytochemical content and resulting antioxidant capacities (Çalışkan and Polat, 2011; Solomon et al., 2006). For example, black colored cultivars have three times higher antioxidant capacity, five times higher anthocyanin contents and two times higher total phenolic contents than yellow and green cultivars (Kösoğlu et al., 2013) Thus, it is clear that the increase of the use of ignored dark-colored fig cultivars in drying could increase the trade, consumption and potential health benefits obtained from colored fig fruits.

The aim of the present study is to compare the general characteristics, total polyphenol contents and antioxidant capacities of two dark-colored (black) and two lightcolored (yellow) fig cultivars selected from genetic collection of Turkish fig research institute. The figs were tested when they were fresh and after sun-drying and oven-drying. This work makes a contribution in that it showed the sharp differences in bioactive potentials of dark-colored and light-colored figs and it determined the effects of industrially important drying methods on bioactive constituents of dark-colored figs.

\section{MATERIALS AND METHODS}

\section{Materials}

The dark-colored (TR1101, TR1102) and the light-colored (TR1029 ('Sarllop'), TR1098 ('Sarızeybek')) fig cultivars were obtianed from the collection garden of fig research institute (Aydın, Turkey). The fresh fully ripe fruits were harvested and fresh fruit characteristics were determined. The fruits to be dried were kept on the trees for overripening and harvested after the moisture content decreased to $40-50 \%$ between July 25 and September 5 . The harvested fruits were used in sun-drying or oven-drying studies. The fresh and dried fig samples were stored at $-20^{\circ} \mathrm{C}$ until used for analysis. ABTS $(2,20$-azino-bis-(3ethylbenz-thiazoline-6-sulfonic acid)) and gallic acid (3,4,5-trihydroxybenzoic acid) were purchased from Sigma Chem. Co. (St. Louis, Mo., USA). Trolox (6-hydroxy-2,5,7,8tetramethylchroman- 2-carboxylic acid) was purchased from Fluka (Switzerland).

\section{Drying processes}

Two methods, sun-drying and oven-drying, were used to obtian the final dried figs at moisture content between 20 and 26\%. In the sun-drying the semi-dried figs were dried for 2-3 days under the sun. In the oven drying the semi-dried figs were kept in the oven for 12$16 \mathrm{~h}$ at $60^{\circ} \mathrm{C}$ and at the air velocity of $0.5 \mathrm{~m} \mathrm{~s}^{-1}$.

\section{Physicochemical analysis}

The moist contents of figs were determined with DFA-Dried Fruit Analysis, California. The surface colour of dried figs was measured for 20 dried figs with Minolta CR-400, Japan. Total soluble solids (TSS) content was determined with a refractometer (Atago PAL-3, Japan). The titrable acidity (TA) was determined by titration with $0.1 \mathrm{~N} \mathrm{NaOH}$. The results of TA were expressed as g citric acid $100 \mathrm{~g}^{-1}$ of fresh weight. The peel thickness was measured with a digital kumpas (Astor 300, Germany). Sensory evaluation was performed with a panel group consisting of 25 people among experienced fig research institute staff.

\section{Extraction of phenolic compounds}

A two step extraction process was applied to obtain first the aqueous extract and then the ethanolic extract that contain hydrophilic and lipophilic phenolic compounds, respectively. The aquous extract was obtained by homogenization of $100 \mathrm{~g}$ fresh or $20 \mathrm{~g}$ dry 
fig sample with $60 \mathrm{~mL}$ of cold water $\left(4^{\circ} \mathrm{C}\right)$ in a Waring blender for $2 \mathrm{~min}$. Then, $2 \mathrm{~g}$ of homogenat was mixed with $12 \mathrm{~mL}$ of additional cold water and the slurry obtained was further homogenized in a disperser-homogenizer (IKA-T 18, Brasil) at 18,000 rpm for $2 \mathrm{~min}$. The final homogenate was then centrifuged at $4600 \times \mathrm{g}$ at $4^{\circ} \mathrm{C}$ for $20 \mathrm{~min}$. The collected supernatant containing the aquous extract was filtered and kept in an ice water bath. On the other hand, the ethanolic extract was prepared by suspending the pellet in $12 \mathrm{~mL}$ ethanol $(96 \%)$ and homogenizing this suspension in disperser-homogenizer at $18,000 \mathrm{rpm}$ for 4 min. The extract was then clarified by centrifugation at $4600 \times \mathrm{g}$ at $4^{\circ} \mathrm{C}$ for $15 \mathrm{~min}$. This clear extract cocntaining the ethanolic extract was kept in an ice-water bath.

\section{Total antioxidant activity}

Trolox equivalent antioxidant capacity (TEAC) of aqueous and ethanolic figs extracts were determined spectrophotometrically (PG, Model T80, United Kingdom) according to the method of Re and others (1999) by monitoring ABTS radical cation decolourization caused by test samples at $734 \mathrm{~nm}$. The total antioxidant activity of figs was determined by finding the sum of aqueous and ethanolic extracts.

\section{Total phenolic content}

The phenolic content of the aqueous and ethanolic fig extracts was determined spectrophotometrically according to the Folin-Ciocalteu procedure of Singleton and Rossi using Folin-Ciocalteu as reactive reagent and gallic acid (GA) as standard (Singleton and Rossi, 1965). The total phenolic contents of figs were determined by finding the sum of phenolic contents for aqueous and ethanolic extracts.

\section{Statistical analysis}

The statistical analysis was conducted by analyzing data for the analysis of variance. Significant differences among means were determined by the least significant difference (LSD) with a significance level of 0.05 .

\section{RESULTS AND DISCUSSION}

\section{Characteristics of fresh and dried figs}

The photos of two dark-colored and two light-colored fresh fruits are presented in Figure 1 while some general characteristics of fresh fruits are presented in Table 1.

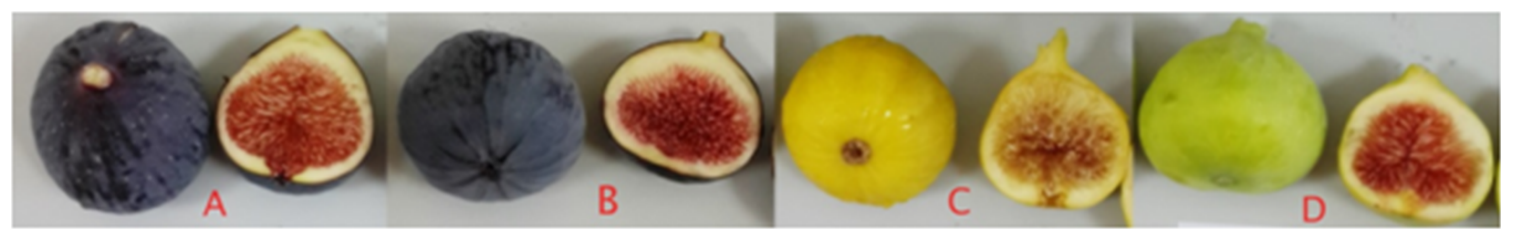

Figure 1. Photos of two dark-colored and two light-colored fresh fruits. (A: TR1101, B: TR1102, C: TR1029, D: TR1098).

Table 1. Analysis results of TA, pH and TSS values in fresh fruit samples.

\begin{tabular}{lccc}
\hline Sample code & TA $(\%)$ & pH & TSS $(\%)$ \\
\hline TR1101 & 0.16 & 5.4 & 26.27 \\
TR1102 & 0.29 & 4.8 & 25.13 \\
TR1029 & 0.14 & 4.9 & 20.23 \\
TR1098 & 0.21 & 4.8 & 24.00 \\
\hline
\end{tabular}

The titrable acidity of fresh fruits showed some variation and changed between 0.14 and $0.29 \%$ while the $\mathrm{pH}$ of the fresh fruits showed less variation and changed between 4.8 and 5.4. The total soluble solids (TSS) content of dark-colored fresh fruits were quite similar, 
but slightly to moderately higher than those of light-colored fresh fruits. However, it should be reported that these physicochemical values are consistent with those data reported for mature fresh figs in the literature (Şahin et al., 2001; Kösoğlu et al., 2013).

The major characteristics of sun-dried fruits are presented in Table 2. Due to the large size of light-colored fruits, the final weights of dried dark-colored fruit cultivars were considerably lower than those of the dried light-colored ones. The final moisture contents of the fruits changed between 24.2 and $28.6 \%$, while the final TSS and titrable acidities of fruits varied between 66.5 and $71.5 \%$, and 0.70 and $1.13 \%$, respectively. It is worth to report that there were almost no differences among the taste scores of dark- and light-colored dried figs. This finding is important since the light-colored figs used in this study are the main commercial fig cultivars that sun-dried and exported from Turkey. The skin thicknesses of dark-colored figs were also quite similar with those of light-colored fruits which are already used successfully for sun-drying.

Table 2. Some physicochemical and sensory properties of the dried fruit samples.

\begin{tabular}{lccccccc}
\hline $\begin{array}{l}\text { Sample } \\
\text { code }\end{array}$ & $\begin{array}{c}\text { Fruit } \\
\text { weight } \\
\mathbf{( g )}\end{array}$ & $\begin{array}{c}\text { Overall } \\
\text { taste } \\
(\mathbf{1}-7)\end{array}$ & $\begin{array}{c}\text { Skin } \\
\text { thickness } \\
(\mathbf{m m})\end{array}$ & $\begin{array}{c}\text { Fruit } \\
\text { colour } \\
\mathbf{( L )}\end{array}$ & $\begin{array}{c}\text { Moisture } \\
(\mathbf{\%})\end{array}$ & $\begin{array}{c}\text { TSS } \\
(\%)\end{array}$ & $\begin{array}{c}\text { TA } \\
(\%)\end{array}$ \\
\hline TR1101 & $16.8 \pm 0.9^{\mathrm{b}}$ & $6.0 \pm 1.0 \mathrm{a}$ & $1.14 \pm 0.37^{\mathrm{b}}$ & $24.1 \pm 5.5^{\mathrm{c}}$ & $27.1 \pm 1.4^{\mathrm{b}}$ & $66.5 \pm 2.5^{\mathrm{b}}$ & $0.95 \pm 0.16^{\mathrm{b}}$ \\
TR1102 & $11.7 \pm 1.7^{\mathrm{c}}$ & $5.2 \pm 1.8^{\mathrm{b}}$ & $1.10 \pm 0.43^{\mathrm{b}}$ & $25.1 \pm 6.6^{\mathrm{c}}$ & $24.2 \pm 1.3^{\mathrm{c}}$ & $67.2 \pm 4.0 \mathrm{~b}$ & $1.13 \pm 0.11^{\mathrm{a}}$ \\
TR1029 & $23.4 \pm 2.1^{\mathrm{a}}$ & $6.1 \pm 0.9^{\mathrm{a}}$ & $1.17 \pm 0.43^{\mathrm{b}}$ & $60.4 \pm 9.8^{\mathrm{a}}$ & $24.7 \pm 0.5^{\mathrm{c}}$ & $71.5 \pm 2.7 \mathrm{~b}$ & $0.88 \pm 0.19 \mathrm{~b}$ \\
TR1098 & $22.4 \pm 1.2^{\mathrm{a}}$ & $5.7 \pm 1.2^{\mathrm{ab}}$ & $1.38 \pm 0.70^{\mathrm{a}}$ & $52.9 \pm 9.9^{\mathrm{b}}$ & $28.6 \pm 0.6^{\mathrm{a}}$ & $67.8 \pm 3.8^{\mathrm{b}}$ & $0.70 \pm 0.07 \mathrm{c}$ \\
\hline
\end{tabular}

The values in the same column are grouped according to $P \leq 0,05$ with $L S D$ test.

\section{Phenolic content and antioxidant capacity of fresh figs}

The results for total phenolic contents and antioxidant capacities of fresh dark-colored and light-colored figs are presented in Table 3. The total phenolic contents and antioxidant capacities of fresh figs showed a great variation and changed between 250,6 and 574,3 $\mathrm{mg}$ GA $100 \mathrm{~g} \mathrm{~g}^{-1}$ d.w., and 55,5 and 144,3 mg GA $100 \mathrm{~g}^{-1}$ f.w., and 346.1 and $858.6 \mu \mathrm{mol}$ Trolox 100 $\mathrm{g}^{-1}$ d.w, and 70 and $216 \mu \mathrm{mol}$ Trolox $100 \mathrm{~g}^{-1}$ f.w, respectively. As expected, the dark-colored fresh figs showed almost 1,5-2,3 fold higher total phenolic content, and 1,9 to 3,0 fold higher antioxidant capacity than the light-colored fresh fig cultivars. The total phenolic contents reported in the present study were very close to the range of total phenolic contents reported by Çalışkan and Polat (2011). These workers studied with 76 fresh figs from eastern Mediterranean coast of Turkey and reported that the total phenolic contents of figs varied between 69,1 and $220 \mathrm{mg} \mathrm{GAE} 100 \mathrm{~g}^{-1}$ f.w. (compare with f.w. results in Table 3). Kösoğlu et al. (2013) also studied the total phenolic contents of 233 fig cultivars grown in Turkey and determined that the phenolic contents of figs varied between 18,28 and 193,10 mg 100 g-1 $^{-1}$.w.

\section{Effect of different drying method on phenolic content and antioxidant capacity of dried figs}

The results for total phenolic contents and antioxidant capacities of dried dark-colored and light-colored figs are also presented in Table 3 . The total phenolic contents and antioxidant capacities of dried figs also varied considerably and changed between 245,6 and 553,7 mg GA $100 \mathrm{~g}^{-1}$ d.w., and 169 and 375,4 GA $100 \mathrm{~g}^{-1}$ f.w., and 387.3 and $674.6 \mu \mathrm{mol}$ Trolox $100 \mathrm{~g}^{-1} \mathrm{~d} . \mathrm{w}$, and 278,8 and $447 \mu \mathrm{mol}$ Trolox $100 \mathrm{~g}^{-1}$ f.w., respectively. The dark-colored dried figs showed almost 1,4-2,3 fold higher total phenolic contents than the light-colored fig cultivars. However, the drying caused $15-30 \%$ reduction in the antioxidant activity of darkcolored figs due to the possible degradation of heat labile anthocyanins in these figs. The degradation of anthocyanins might cause polymerization of the phenolic compounds and this might reduce the accessibility of free radical scavenging groups. On the other hand, it is also worth to report that the antioxidant activity of light-colored figs increased $15-35 \%$ by 
drying. It seemed that the increased antioxidant activity of light-colored figs by drying was due to the formation of Maillard reaction products which are known with their free radical scavenging capacities (Cemeroğlu and Acar, 1986). However, besides all these disadvantages the use of dark-colored fig cultivars in drying still caused 15-74\% higher antioxidant activity than the use of light colored figs in drying. On the other hand, it should also be reported that in three of four fig cultivars no significant differences were found in phenolic content or antioxidant activities of figs dried by sun-drying and oven-drying.

Table 3. Phenolic content and antioxidant activities of fresh and oven dry and sun dry figs.

\begin{tabular}{|c|c|c|c|c|c|}
\hline \multirow{2}{*}{$\begin{array}{l}\text { Sample } \\
\text { code }\end{array}$} & \multirow{2}{*}{$\begin{array}{l}\text { Drying } \\
\text { method }\end{array}$} & \multicolumn{2}{|c|}{$\begin{array}{c}\text { Total phenolic }\left(A E+E^{1}\right) \\
\left(m g \text { GA } 100 \mathrm{~g}^{-1}\right)\end{array}$} & \multicolumn{2}{|c|}{$\begin{array}{l}\text { Antioxidant activity }(\mathrm{AE}+\mathrm{EE}) \\
\left(\mu \mathrm{mol} \text { trolox } 100 \mathrm{~g}^{-1}\right)\end{array}$} \\
\hline & & $\mathrm{FW}^{2}$ & DW & $\mathrm{FW}$ & DW \\
\hline \multirow[t]{3}{*}{ TR1101 } & Sun dried & $274.41 \pm 28.51^{d}$ & $421.75 \pm 41.42 d$ & $418.35 \pm 5.29 a b c$ & $645.80 \pm 16.13^{b}$ \\
\hline & Oven dried & $339.25 \pm 14.60 b$ & $498.89 \pm 21.48^{b}$ & $445.28 \pm 6.91$ ab & $654.82 \pm 10.16^{b}$ \\
\hline & Fresh & $105.08 \pm 4.82^{h}$ & $400.13 \pm 20.98 d$ & $208.20 \pm 6.84^{f}$ & $793.31 \pm 30.61$ \\
\hline \multirow[t]{3}{*}{ TR1102 } & Sun dried & $305.40 \pm 7.72^{c}$ & $459.98 \pm 8.71^{c}$ & $406.08 \pm 38.51 \mathrm{bc}$ & $614.41 \pm 47.18$ bc \\
\hline & Oven dried & $375.39 \pm 19.98$ a & $553.72 \pm 59.92^{a}$ & $446.97 \pm 9.69$ а & $674.55 \pm 38.97 b$ \\
\hline & Fresh & $144.32 \pm 2.50 \mathrm{~g}$ & $574.28 \pm 13.73$ & $215.99 \pm 11.97^{f}$ & $858.57 \pm 40.09$ a \\
\hline \multirow[t]{3}{*}{ TR1029 } & Sun dried & $186.92 \pm 8.68$ ef & $259.61 \pm 12.05$ ef & $332.76 \pm 4.38 d$ & $462.16 \pm 6.08 \mathrm{~d}$ \\
\hline & Oven dried & $193.25 \pm 4.56 \mathrm{e}^{\mathrm{e}}$ & $272.54 \pm 9.26$ ef & $278.83 \pm 3.85 \mathrm{e}$ & $387.26 \pm 5.34 \mathrm{e}$ \\
\hline & Fresh & $55.54 \pm 3.11$ & $274.46 \pm 13.07$ ef & $70.03 \pm 6.15 \mathrm{~g}$ & $346.08 \pm 32.92 \mathrm{e}$ \\
\hline \multirow[t]{3}{*}{ TR1098 } & Sun dried & $168.96 \pm 0.43^{f}$ & $245.60 \pm 2.27^{f}$ & $319.62 \pm 10.01 d$ & $467.21 \pm 11.90 d$ \\
\hline & Oven dried & $193.52 \pm 4.49 \mathrm{e}$ & $289.82 \pm 5.72$ e & $385.24 \pm 11.96 \mathrm{c}$ & $564.93 \pm 19.19 c$ \\
\hline & Fresh & $60.15 \pm 1.15$ & $250.64 \pm 5.82^{f}$ & $99.40 \pm 1.24 \mathrm{~g}$ & $415.05 \pm 6.02 \mathrm{de}$ \\
\hline
\end{tabular}

${ }^{1} \mathrm{AE}$ : aqueous extract, $\mathrm{EE}:$ ethanolic extract.

${ }^{2} \mathrm{FW}$ : fresh weight, DW: dry weight.

The values in the same column are grouped according to $P \leq 0,05$ with $L S D$ test.

\section{CONCLUSIONS}

This study clearly showed the significantly higher phenolic contents and antioxidant capacities of dark-colored figs than the traditionally grown light-colored fig cultivars. The drying did not have a considerable negative effect on total phenolic content of figs. However, heat induced changes in nature of phenolic compounds caused $15-30 \%$ reduction in antioxidant activity of dark-colored figs. The overall results still strongly indicate the good potential of using dark-colored figs in drying and obtaining dried figs with higher bioactive potential.

\section{ACKNOWLEDGEMENTS}

The authors gratefully acknowledge the Ministry of Food, Agriculture and Livestock General Directorate of Agricultural Research And Policies, Ege Exportes Union and all authors and referees for their contributions.

\section{Literature cited}

Çalışkan, O., and Polat, A.A. (2011). Phytochemical and antioxidant properties of selected fig (Ficus carica L.) accessions from the eastern Mediterranean region of Turkey. Sci. Hortic. (Amsterdam) 128 (4), 473-478 http://dx.doi.org/10.1016/j.scienta.2011.02.023.

Cemeroğlu, B., and Acar, J. (1986) Meyve ve Sebze İşleme Teknolojisi, Gıda Teknolojisi Derneği (Ankara, Türkiye).

Haug, M.T., King, E.S., Heymann, H., and Crisosto, C.H. (2013). Sensory profiles for dried fig (Ficus carica L.) cultivars commercially grown and processed in California. J. Food Sci. 78 (8), S1273-S1281. PubMed http://dx.doi.org/10.1111/1750-3841.12196

Kösoğlu, İ., Konak, R., Tan, N., Kocataş, H., Yamaner, Ç., and Yemenicioğlu, A. (2013). İncir Genetik Kaynaklarının Toplam Fenolik Madde ve Toplam Antioksidan İçeriği İncir Araştırma Enstitüsü Proje Sonuç Raporu (Türkiye). 
Özen, M., Çobanoğlu, F., Özkan, R., Kocataș, H., Tan, N., Ertan, B., Şahin, B., Konak, R., Doğan, Ö., Tutmuș, E., and Şahin, N. (2007). İncir Yetiştiriciliği (Aydın İncir Araştırma Enstitüsü) ISBN:978-975-407-224-2.

Re, R., Pellegrini, N., Proteggente, A., Pannala, A., Yang, M., and Rice-Evans, C. (1999). Antioxidant activity applying an improved ABTS radical cation decolorization assay. Free Radic. Biol. Med. 26 (9-10), 1231-1237. PubMed http://dx.doi.org/10.1016/S0891-5849(98)00315-3

Şahin, N., Aksoy, U., and Akçay, M. (2001). İncir çeşit kataloğu (Aydın İncir Araştırma Enstitüsü).

Singleton, V.L., and Rossi, J.J.A. (1965). Colourimetry of total phenolics with phosphomolybdic phosphotungstic acid reagents. Am. J. Enol. Vitic. 16, 144-158.

Solomon, A., Golubowicz, S., Yablowicz, Z., Grossman, S., Bergman, M., Gottlieb, H.E., Altman, A., Kerem, Z., and Flaishman, M.A. (2006). Antioxidant activities and anthocyanin content of fresh fruits of common fig (Ficus carica L.). J. Agric. Food Chem. 54 (20), 7717-7723. PubMed http://dx.doi.org/10.1021/jf060497h

Trichopoulou, A., Vasilopoulou, E., Georga, K., Soukara, S., and Dilis, V. (2006). Traditional foods: why and how to sustain them. Trends Food Sci. Technol. 17 (9), 498-504 http://dx.doi.org/10.1016/j.tifs.2006.03.005.

Vinson, J.A. (1999). The functional foods: properties of figs. Cereal Foods World 44, 82-87.

Vinson, J.A., Hao, Y., Su, X., and Zubik, L. (1998). Phenol antioxidant quantity and quality in foods: vegetables. J. Agric. Food Chem. 46 (9), 3630-3634 http://dx.doi.org/10.1021/jf980295o.

Vinson, J.A., Zubik, L., Bose, P., Samman, N., and Proch, J. (2005). Dried fruits: excellent in vitro and in vivo antioxidants. J Am Coll Nutr 24 (1), 44-50. PubMed http://dx.doi.org/10.1080/07315724.2005.10719442 